\title{
Muscle adaptation in response to a high-intensity interval training in obese older adults: effect of daily protein intake distribution
}

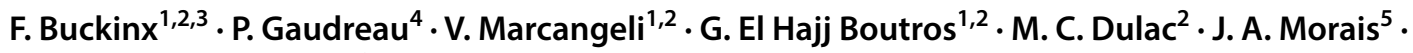 \\ M. Aubertin-Leheudre ${ }^{1,2}$
}

Received: 17 December 2018 / Accepted: 11 February 2019

(c) Springer Nature Switzerland AG 2019

\begin{abstract}
Background Aging is associated with declines in muscle mass, strength and quality, leading to physical impairments. An even protein distribution in daily meals has recently been proposed along with adequate total protein intake as important modulators of muscle mass. In addition, due to its short duration, high-intensity interval training (HIIT) has been highlighted as a promising intervention to prevent physical deterioration. However, the interaction between daily protein intake distribution and HIIT intervention in elderlies remain unknown.

Objective To investigate muscle adaptation following HIIT in older adults according to daily protein intake distribution.

Methods Thirty sedentary obese subjects who completed a 12-week elliptical HIIT program were matched [criteria: age ( \pm 2 years), sex, BMI $\left.\left( \pm 2 \mathrm{~kg} / \mathrm{m}^{2}\right)\right]$ and divided a posteriori into 2 groups according to the amount of protein ingested at each meal: $<20 \mathrm{~g}$ in at least one meal (P20-, $n=15,66.8 \pm 3.7$ years) and $\geq 20 \mathrm{~g}$ in each meal ( $\mathrm{P} 20+, n=15,68.1 \pm 4.1$ years). Body composition, functional capacity, muscle strength, muscle power, physical activity level, and nutritional intakes were measured pre- and post-intervention. A two way repeated ANOVA was used to determine the effect of the intervention (HIIT) and protein distribution ( $\mathrm{P} 20-$ vs $\mathrm{P} 20+, p<0.05)$.

Results No difference was observed at baseline between groups. Following the HIIT intervention, we observed a significant decrease in waist and hip circumferences and improvements in functional capacities in both $\mathrm{P} 20-$ and $\mathrm{P} 20+$ group $(p<0.05)$. However, no protein distribution effect was observed.

Conclusion A 12-week HIIT program is achievable and efficient to improve functional capacities as well as body composition in obese older adults. However, consuming at least $20 \mathrm{~g}$ of proteins in every meal does not further enhance muscle performance in response to a 12-week HIIT intervention.
\end{abstract}

Keywords Protein distribution $\cdot$ Exercise $\cdot$ Nutrition $\cdot$ Muscle $\cdot$ Functional capacities $\cdot$ Obesity $\cdot$ Body composition $\cdot$ Aging

M. Aubertin-Leheudre

aubertin-leheudre.mylene@uqam.ca

1 Département des Sciences de l'activité physique, Faculté des Sciences, UQAM, Groupe de Recherche en Activité Physique Adaptée (GRAPA), Université du Québec à Montréal, Pavillon Sciences Biologiques, SB-4615, 141, Avenue du Président Kennedy, Montréal, QC H2X 1Y4, Canada

2 Centre de Recherche de l'Institut Universitaire de Gériatrie de Montréal (CRIUGM), Montréal, Canada
3 WHO Collaborating Centre for Public Health Aspects of Musculoskeletal Health and Ageing, Liège, Belgium

4 Département de médecine de l'Université de Montréal, Centre de recherche du Centre Hospitalier Universitaire de Montréal (CRCHUM), Université de Montréal, Montréal, Canada

5 Division of Geriatric Medicine, McGill University Health Centre (MUHC), McGill University, Montréal, QC, Canada 


\section{Introduction}

Aging is perceived as a condition contributing greatly to a deterioration of the quality of life [1]. One major health challenge in the aging population is to slow down the decline of muscle mass, strength and quality (i.e., muscle strength/muscle mass), to prevent functional impairments and disabilities leading to a gradual loss of autonomy [2-4].

Among the many etiological factors, several aspects of protein intake are thought to contribute to the decline in muscle mass, strength and quality during aging: daily amount, distribution over the day, per-meal amount and protein quality [5-7]. Firstly, the protein quality affects muscle synthetic response [8]. The quality of a protein is determined by assessing its essential amino acid composition, digestibility and bioavailability of amino acids [9]. More precisely, the quality of a meal is determined by its leucine content, with regard to the stimulation of muscle protein synthesis [10]. Based on the PROT-AGE study, at least $2.5 \mathrm{~g}$ of leucine per meal is recommended for healthy older adults [11]. Current literature suggests that, compared with animal proteins, the ingestion of plant proteins (e.g., in soy and wheat) results in a lower muscle protein synthesis and that animal protein intake might be of relevance for the maintenance of muscle mass [12]. A possible explanation is the relative lack of specific essential amino acids (i.e., low leucine content) in plant as opposed to animal-based proteins. Secondly, a reduced amount of daily protein intake plays a role in the onset of muscle mass, strength and quality decline with aging. Indeed, compared to younger adults, older adults usually eat less, including less protein [13]. At the same time, older adults need more dietary protein than do younger adults due to anabolic resistance [11]. The actual daily recommended allowance (RDA) advocates that $0.8 \mathrm{~g} \mathrm{~kg}^{-1}$ $\mathrm{day}^{-1}$ for both men and women aged over 19 years is sufficient to meet daily protein needs [14]. Thus, to help older people ( $>65$ years) to maintain or regain lean body mass and function, the PROT-AGE study group recommends average daily intake at least in the range of 1.0 to $1.2 \mathrm{~g}$ protein $\mathrm{kg}^{-1} \mathrm{day}^{-1}$ per day [11]. In the Health, Aging, and Body Composition study, which included 2066 men and women aged 70-79 years, participants in the highest quintile of protein intake (i.e., $1.2 \mathrm{~g} \mathrm{~kg}^{-1} \mathrm{day}^{-1}$ ) lost approximately $40 \%$ less total and appendicular lean mass compared to the group in the lowest quintile of protein intake (i.e., $0.8 \mathrm{~g} \mathrm{~kg}^{-1} \mathrm{day}^{-1}$ ) [15]. Nevertheless, a significant proportion of older adults are consuming much lower levels of proteins than those recommended by the PROTAGE group [13]. Based on the accurate weighing food method, the average consumption of protein reported in nursing home residents was $0.88 \pm 0.25 \mathrm{~g} \mathrm{~kg}^{-1} \mathrm{day}^{-1}$ [16] Therefore, high dietary protein intake has been proposed as an important factor to maintain physical performance in older adults [17]. Moreover, an even protein distribution in daily meals along with an appropriate amount of protein intake in each meal has been recently suggested to increase muscle mass [18]. Moore et al. (2009) showed that $20 \mathrm{~g}$ of protein was the minimum amount needed per meal to maximally stimulate muscle protein synthesis in older adults [19]. Thus, it has been recently shown that an even protein intake distribution across meals has more benefits the following $24 \mathrm{~h}$ on muscle protein synthesis and lean mass loss compared to a skewed protein distribution [20]. The positive influence of protein distribution on muscle protein synthesis has been highlighted among community-dwelling seniors aged 75 years or older (frail or robust) [21], malnourished or at-risk patients in rehabilitation units [22] and in healthy adults [23].

In addition, exercise strategies have been largely linked to improvements in muscle mass, strength and quality [24]. In this sense, it has been shown that aerobic training (i.e., Recreational exercise habits such as walking, swimming,...) are as beneficial as resistance trainings for maintaining muscle quality and mitigate functional capacities decline among older adults aged over 60 years [25]. Because older adults report lack of time for physical activity, high-intensity interval training (HIIT) has been highlighted as a promising aerobic intervention in elderly population due to its short duration. More importantly, it has been observed that HIIT improved body composition (total or appendicular fat and lean masses), muscle function (muscle mass and power), aerobic capacities $\left(\mathrm{VO}_{2 \max }\right)$ or reduced cardiometabolic risk factors (waist circumference, waist-hip circumference ratio, diastolic blood pressure and fasting glucose levels) in older adults [26-33]. Finally, HIIT elicited similar or higher enjoyment and adherence levels than moderate-intensity continuous training $[34,35]$.

However, a paucity of interventional studies exists that critically assess whether within-day protein intake distribution influence muscle adaption following exercise training. In this sense, our group recently suggested that the initial amount of protein could influence the muscle adaptation (i.e., gains in muscle strength and quality) following an exercise training in older adults $[36,37]$. Up to now, the effectiveness of resistance training to improve body composition or muscle function (muscle strength, anabolic response, functional outcomes) [24], in combination with or without dietary energy restriction, was not shown to be influenced by the within-day distribution of proteins, when day-to-day protein consumption is adequate [38, 39]. However, despite the well-known benefits of HIIT on muscle function, the influence between daily protein intake distribution and 
muscle adaptation following HIIT intervention in the elderly remains unknown.

Therefore, the present study aimed to investigate muscle adaptation following a HIT according to baseline daily protein intake distributions in older adults.

\section{Methods}

\section{Study design and population}

This study is a posteriori study design. Subjects were recruited from the community via social communication (flyers and meetings in community centers) in the Great Montreal area. To be included in this study, subjects had to meet the following criteria: (1) aged 60 years and over, (2) inactive for at least 6 months $(<2 \mathrm{~h} /$ week of structured exercise), (3) obese [fat mass (FM): men $>25 \%$, women $>35 \%$; [40]], (4) a stable weight ( $\pm 2 \mathrm{~kg})$ over the past 6 months, (5) no orthopedic limitations, (6) no counter-indication to practice physical activity (Physical Activity Readiness Questionnaire), (7) absence of menstruation for the past 12 months for women, (8) no smoker and, (9) no excessive alcohol consumers ( $\geq 2$ drinks/day). Subjects with diagnosed (untreated) neurological, cardiovascular, lung diseases or cognitive disorders were also excluded.

Based on their protein intake, participants were a posteriori divided in 2 groups according to Moore's cut-point (20 g of protein per meal [19]): (1) P20 $-[n=15$ (men: $n=7 /$ women: $n=8)$ ]: subjects who consume $<20 \mathrm{~g}$ of protein in at least one meal; (2) P20+ [ $n=15$ (men: $n=7 /$ women: $n=8$ )]: subjects who consume $\geq 20 \mathrm{~g}$ of protein in each meal. The participants included in each group were matched according to sex, age ( \pm 2years) and BMI $\left( \pm 2 \mathrm{~kg} / \mathrm{m}^{2}\right)$ and have completed a 12-week of HIIT intervention.

The calculation of our statistical power was performed a posteriori using G Power Software. Considering the $t$ test family (Wilcoxon and Mann Whitney tests for two groups) and $\alpha=0.05$, sample size group $1=15$; group $2=15$, Effect size $=1.0$ for normally distributed data. In these conditions, a statistical power $\sim 0.70$ was obtained.

All procedures were approved by the Ethics Committee of the Université du Québec à Montréal (UQAM). All participants provided informed written consent after having received information on nature, goal, procedures and risks associated with the study.

\section{Intervention}

The HIIT was performed three times per week in nonconsecutive days during 12 weeks and was supervised by trained health professionals (i.e., kinesiologist). The sessions were realized on an elliptical device to reduce lower extremity joint impact [28]. The intensity of each cycle was based on the percentage of maximal heart rate (MHR) and/or perceived exertion (Borg scale) [41]. The MHR was determined using the validated equation of Karvonen [( $220-$ age $)-$ HR rest $) \times \%$ HR target $]+$ HR rest [42]. More specifically, the $30 \mathrm{~min}$ exercise session consisted of a 5 min warm-up at a low intensity (50-60\% MHR and/or a 6 score between 8 and 12 on the Borg scale); a 20-min HIIT of multiples 30-sec sprints at a highintensity (80-85\% MHR or Borg' scale $>17$ ) alternating with sprints of $90 \mathrm{~s}$ at a moderate-intensity (65\% MHR or Borg'scale score 13-16); and a 5-min cool-down (50-60\% MHR and/or a Borg' scale score 8-12). To ensure that MHR was always above $80 \%$ during high-intensity intervals, speed and resistance of the elliptical device were continuously adjusted throughout the training session. Participants needed to complete $80 \%$ or more of their training sessions to be included in the analysis [28].

\section{Measurements}

Assesments took place at the Département des Sciences de l'activité physique of the Université du Québec à Montréal. Body composition, muscle strength, muscle quality, functional capacities and energy balance were evaluated at baseline and at the end of the training protocol.

\section{Body composition}

Body weight and height were determined using an electronic scale (Omron HBF-500CAN) and a stadiometer (Seca), from which body mass index $[\mathrm{BMI}=$ body mass $(\mathrm{kg}) /$ height $\left(\mathrm{m}^{2}\right)$ ] was calculated. Waist circumference (WC) and hip circumference (HC) were measured to the nearest $0.1 \mathrm{~cm}$.

Total fat mass [FM (\%)], android fat mass (\%) and leg fat mass $(\%)$, total lean body mass [LBM $(\mathrm{kg})]$, appendicular lean mass [App LM $\left(\mathrm{km} / \mathrm{m}^{2}\right)$ ] were determined by Dualenergy X-ray absorptiometry (DXA) using a Lunar Prodigy whole-body scanner (GE Medical Systems, Madison, WI, USA) in conjunction with Encore 2002 software. The instrument automatically alters scan depth depending on the thickness of the subject, as estimated from age, height, and weight. All scans were performed while the subjects were wearing light indoor clothing and no removable metal objects. The typical scan time was 5 min, depending on height. The radiation exposure per whole-body scan is estimated to be $2 \mu \mathrm{Sv}$, which is lower than the daily background level. The precision of soft tissue analysis established by repeat measurements of humans on 4 successive days, has been reported as $1 \%$ for FFM and $2 \%$ for FM $[43,44]$. 


\section{Functional capacities}

Mobility and aerobic capacities were evaluate using the 6-min walking tests (6MWT). Participants were asked to walk as much as possible for 6 min. Every minute of the test, volunteers received the same standardized encouragement according to the American College of Chest Physicians recommendations for the 6-min walking test [31]. Participants were allowed to interrupt and return to exercising as well as to reduce or increase speed according to perceived effort [45]. The distance, in meters, was recorded and used as an indicator of mobility capacity. In addition, aerobic capacity (estimated $\mathrm{VO}_{2 \max }$ in $\mathrm{mL} \cdot \mathrm{kg}^{-1} \cdot \mathrm{min}^{-1}$ ) was estimated based on the total distance realized during $6 \mathrm{~min}$ and according to the following validated equation: $70.161+[0.023 \times$ distance $(\mathrm{m})]-[0.276 \times$ body weight $(\mathrm{kg})]-[6.79 \times \operatorname{sex}(\operatorname{men}=0$, women $=1])-[0.193 \times \mathrm{HR}$ (pulse/min) $]-[0.191 \times$ age $($ years) $]$ [46].

The validated 4-m walking test [4MWT] which is the most commonly used test to evaluate physical performance $[47,48]$ was performed at usual self-pace and fast speed. The time (in seconds) needed to cover the entire distance was recorded [37].

Walking speed was estimated using the "Timed Up \& Go" test (in s). This test consists of a complete task of standing from a chair, walking a 3-m distance and sitting down again [49] was performed in comfortable and self-paced and in fast-paced walking speed. A duration above $30 \mathrm{~s}$ indicates limited mobility and an increased risk of falling whereas a duration of less than $20 \mathrm{~s}$ indicates appropriate mobility with the subject being likely to be independent in activities of daily living [50].

Lower-body function was measured using the chair stand test. The subjects were asked to stand up from a sitting position and to sit down 10 times as fast as possible, with arms folded across their chest [51] and the time (in seconds) to realize the task was recorded.

The ability of weight shifting in the forward and upward directions was estimated using the alternate-step test. Participants were placed facing toward a $20-\mathrm{cm}$ height step and instructed to touch the top of it with the right and left foot, alternately, as fast as possible during a 20 -s period $[52,53]$. The number of step counts was recorded for analysis.

Balance was assessed using the validated unipodal balance test. During this test with participants standing on both legs and alternately standing on the right and left leg with eyes opened and arms by the side of the trunk. The time was recorded in seconds from the moment one foot was lifted from the floor to when it touched the ground, the stance leg moved, or until $60 \mathrm{~s}$ had elapsed [54].

\section{Muscle function}

Maximum voluntary upper limb muscle strength (ULMS) was measured with a hand dynamometer with adjustable grip (Lafayette Instrument) [55]. This method has been shown to be reliable. Participants were standing upright with the arm along the side of the body with the elbow extended and the palm of the hand facing the thigh. Participants were advised to squeeze as hard as possible the hand dynamometer for up to $4 \mathrm{~s}$. Three measurements for each hand, alternately, were performed and the maximal score of each was recorded. Upper limb muscle strength was expressed in absolute (ULMS; $\mathrm{kg}$ ) and relative (ULMSr: divided by body weight $(\mathrm{BW} ; \mathrm{kg} / \mathrm{kg})$ ) values [56].

Maximal isometric lower limb muscle strength was assessed using a strain gauge system attached to a chair (Primus RS Chair, BTE) upon which participants were seated with the knee and hip joint angles set at $135^{\circ}$ and $90^{\circ}$, respectively. The knee angle was set to $135^{\circ}$, compared to the typical $90^{\circ}$, to diminish the maximal joint torque that could be generated [57, 58], particularly in light of generally more fragile bones in the elderly [59]. The tested leg was fixed to the lever arm at the level of the lateral malleoli on an analog strain gauge to measure strength. The highest of three maximum voluntary contractions was recorded [60]. Lower limb muscle strength was expressed in absolute terms (N) and relative to body weight (divided by body weight $(\mathrm{kg} / \mathrm{kg}))$.

Upper and lower limb muscle quality were calculated using the maximal grip strength $(\mathrm{kg})$ divided by arm lean mass (kg; DXA) and the maximal knee extensor strength (in $\mathrm{kg}$ ) divided by leg lean mass (kg; DXA), respectively [61], both indices known to be related with functional impairments [60, 62].

Lower limb muscle power was measured using the Nottingham Leg Extensor Power rig with the subject in a sitting position [63]. Participants were asked to push the pedal down as hard and fast as possible, accelerating a flywheel attached to an A-D converter [64]. Power was recorded for each push until a plateau/decrease was observed. This assessment has been demonstrated to be safe, sensitive and reliable in older adults.

\section{Muscle composition}

Peripheral Quantitative Computed Tomography (pQCT) scan of the right leg was obtained using the Stratec XCT3000 (STRATEC Medizintechnik GmbH, Pforzheim, Germany, Division of Orthometrix; White Plains, NY, USA) at the $33 \%$ distance of the femur, starting from the lateral epicondyle up to the lateral trochanter. The total length was entered into the software as well as other scanning parameters, such as voxel size $(0.5 \mathrm{~mm})$ and speed $(10 \mathrm{~mm} / \mathrm{s})$. 
All pQCT scans were done by trained operators for $\mathrm{pQCT}$ data acquisition following guidelines provided by Bone Diagnostics, Inc. (Fort Atkinson, WI). Image quality was visually assessed following data acquisition by a second evaluator who analyzed the data. The visual inspection rating scale classified all images as a rate up to 3 , according to a previously reported visual scale of movement artefact [65]. For image analysis, the freely-available source code for the pQCT density distribution plugin for BoneJ (Version 1.3.11) was used [66]. BoneJ's soft-tissue analysis uses a $7 \times 7$ median filter to reduce noise. Soft tissue and bone area and density were defined according to the tissue thresholds selected. Muscular, bone, intramuscular adipose tissue (IMAT) and subcutaneous adipose tissue thresholds were defined based on parameters of a previous study [67] and results were all provided automatically in the BoneJ analysis output. For calf muscle area, density, and subcutaneous fat area precision errors ranges are reported to be between 2.1 and $3.7 \%, 0.7$ and $1.9 \%$, and 2.4 and $6.4 \%$, respectively and for IMAT area, the less accurate measure, varying from 3 to $42 \%$ [67].

\section{Energy balance}

The number of steps and the METS were used to estimate participants level of physical activity using a validated triaxial accelerometer (SenseWear ${ }^{\circledR}$ Mini Armband) as previously described by Brazeau et al. [68], Colbert et al. [69]. Participants had to wear the device in the left arm all the time during 7 consecutive days, except when taking a shower or swimming. Each participant had to wear the device at least $85 \%$ of time to be included in the study.

As previously described and validated in the elderly population, dietary intake was assessed using the 3-day food record method (two weekdays and one weekend day) [51]. Participants were asked not to change their dietary habits during the intervention period. Analyzes of total energy intake as well as protein, lipids or carbohydrates and amino acids (total, essential [EAA] and non-essential [NEAA]) intake in average and during each meal (breakfast, lunch, dinner and snacks) were performed using the software Nutrific $^{\odot}$ according to the standardized Canadian Food file (CNF2015).

\section{Statistical analysis}

Data distribution was tested with the Kolmogorov test. Quantitative variables were expressed by mean \pm standard deviation (SD). Qualitative variables were expressed in percentage. An independent parametric $t$ test was used to identify between-group baseline differences. A paired $t$ test was used to assess the effect of HIIT intervention within group. A repeated-measure general linear model analysis
$(2 * 2$ ANOVA) was used to estimate time and time*group effects (i.e., to compare pre- and post- intervention (HIIT) in P20 - and P20 + groups). All calculations were performed using SPSS 25.0 program (Chicago, IL, USA) and Statistica 10 software. $p \leq 0.05$ was considered statistically significant.

\section{Results}

\section{Population}

A total of 30 obese older adults completed the HIIT ( $>80 \%$ of all sessions) and were divided a posteriori in two matched groups: P20 - ( $n=15$ : women (8)/men (7), $66.8 \pm 3.7$ years) and P20+ ( $n=15$ : women (8)/men (7), $68.1 \pm 4.1$ years). Main characteristics of the population at baseline (pre) and after 12 weeks of intervention (post) are presented in Table 2. Baseline characteristics of the subjects (body composition, muscle composition, functional capacities) were comparable between the 2 groups ( $p \geq 0.05$ ).

The effects of HIIT intervention according to time effects, within group effect and group*time effect, on body composition, functional capacities, muscle composition and energy balance, are described below (Tables 1, 2, 3; Fig. 1).

\section{Body composition}

We only observed a significant decrease in waist and hip circumferences in both $\mathrm{P} 20-(p=0.001 ; p=0.001$ respectively) and P20+ ( $p<0.001 ; p<0.001$ respectively) groups, following the HIIT intervention. However, the waist/hip ratio was not modified by intervention. We also found a significant time (HIIT) effect on waist $(p<0.001)$ and hip $(p<0.001)$ circumferences. However, no group*time effect is observed in body composition parameters.

\section{Functional capacities \& Muscle function}

Concerning functional capacities, we observed significant improvements ( $p$-values ranged between $<0.001$ and 0.05) for TUGn, TUGf, n-4MWT, f-4MWT, Balance, chair test, step test, ULMS, rULMS, muscle power, 6MWT and estimated $\mathrm{VO}_{2 \max }$ following the HIIT intervention in P20- group (Table 2; Fig. 1). Almost the same observations were made in the P20+ group excepted for balance, ULMS, rULMS which are not improved following the HIIT intervention. A significant time (HIIT) effect was observed for TUGn, TUGf, f-4MWT, chair test, step test, muscle power, 6MWT, and estimated $\mathrm{VO}_{2 \max }$. Nevertheless, no significant group $\times$ time effect on functional capacities was shown (Table 2). 
Table 1 Effect of intervention on physical characteristics and body composition

\begin{tabular}{|c|c|c|c|c|c|c|c|c|}
\hline \multirow[t]{2}{*}{ Variables } & \multicolumn{3}{|c|}{ P20- group $(n=15)$} & \multicolumn{3}{|c|}{$\mathrm{P} 20+\operatorname{group}(n=15)$} & \multicolumn{2}{|c|}{$2 * 2$ ANOVA } \\
\hline & Pre & Post & $\begin{array}{l}\text { within-group } \\
\text { effect ( } p \text { value) }\end{array}$ & Pre & Post & $\begin{array}{l}\text { within-group } \\
\text { effect ( } p \text { value) }\end{array}$ & $\begin{array}{l}\text { Time } \\
\text { effect ( } p \\
\text { value) }\end{array}$ & $\begin{array}{l}\text { Time } \times \text { group } \\
\text { effect }(p \text { value })\end{array}$ \\
\hline
\end{tabular}

General characteristics

\begin{tabular}{|c|c|c|c|c|c|c|c|c|}
\hline Age (years) & $66.8 \pm 3.7$ & & & $68.1 \pm 4.1$ & & & & \\
\hline $\operatorname{Sex}(\mathrm{W} ; \%)$ & $8(53 \%)$ & & & $8(53 \%)$ & & & & \\
\hline \multicolumn{9}{|l|}{ Body composition } \\
\hline BW (kg) & $76.8 \pm 13.2$ & $75.9 \pm 13.7$ & 0.21 & $80.5 \pm 7.2$ & $81.1 \pm 7.3$ & 0.32 & 0.75 & 0.11 \\
\hline BMI $\left(\mathrm{kg} / \mathrm{m}^{2}\right)$ & $27.2 \pm 3.3$ & $26.9 \pm 3.4$ & 0.22 & $29.0 \pm 2.4$ & $29.1 \pm 2.5$ & 0.47 & 0.61 & 0.15 \\
\hline $\mathrm{WC}(\mathrm{cm})$ & $100 \pm 11$ & $97 \pm 12$ & 0.001 & $105 \pm 6$ & $102 \pm 7$ & $<0.001$ & $<0.001$ & 0.79 \\
\hline $\mathrm{HC}(\mathrm{cm})$ & $105 \pm 8$ & $101 \pm 9$ & 0.001 & $107 \pm 7$ & $103 \pm 6$ & $<0.001$ & $<0.001$ & 0.71 \\
\hline $\mathrm{WC} / \mathrm{HC}$ & $0.96 \pm 0.2$ & $0.96 \pm 0.1$ & 0.45 & $0.98 \pm 0.2$ & $0.98 \pm 0.1$ & 0.85 & 0.61 & 0.39 \\
\hline Total LM (kg) & $45.3 \pm 9.4$ & $45.6 \pm 9.1$ & 0.35 & $48.1 \pm 7.2$ & $48.7 \pm 8.1$ & 0.11 & 0.07 & 0.63 \\
\hline App LM (kg) & $21.5 \pm 5.1$ & $21.6 \pm 4.9$ & 0.59 & $23.3 \pm 4.0$ & $23.5 \pm 4.3$ & 0.25 & 0.24 & 0.73 \\
\hline Total FM (\%) & $36.9 \pm 8.1$ & $36.0 \pm 7.9$ & 0.20 & $36.7 \pm 6.6$ & $36.6 \pm 7.9$ & 0.76 & 0.23 & 0.43 \\
\hline Android FM (\%) & $46.2 \pm 10.9$ & $45.2 \pm 10.8$ & 0.32 & $47.3 \pm 5.7$ & $46.9 \pm 7.4$ & 0.55 & 0.24 & 0.63 \\
\hline Abdominal FM (\%) & $40.2 \pm 10.4$ & $39.2 \pm 10.8$ & 0.30 & $41.5 \pm 5.0$ & $41.4 \pm 6.7$ & 0.81 & 0.32 & 0.62 \\
\hline Leg FM (\%) & $35.2 \pm 10.3$ & $34.4 \pm 9.7$ & 0.066 & $33.8 \pm 9.8$ & $33.7 \pm 10.8$ & 0.82 & 0.18 & 0.32 \\
\hline
\end{tabular}

Data are presented as means $\pm \mathrm{SD}$

A general linear model repeated measures was conducted to estimate the time and the group $\times$ time effects

$B W$ body weight, $B M I$ body mass index, $W C$ waist circumference, $H C$ hip circumference, $L M$ lean mass, $F M$ fat mass $P \leq 0.05$ : significant

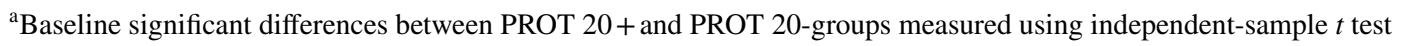

*Within differences between pre- and post-intervention estimated using paired $t$ test

\section{Muscle composition}

As shown in Table 2, the intervention (HIIT) did not induce a significant time or within group change on muscle composition parameters. Furthermore, no time $\times$ group effect was highlighted on muscle composition.

\section{Energy balance (intake and expenditure)}

No difference was observed between groups at baseline on energy expenditure parameters (number of steps or METs). Furthermore, the intervention (HIIT) did not induce a significant time or within group change on energy expenditure (Table 3 ). Finally, no time $\times$ group effect was find.

Nutritional profile and protein intake during each daily meal in each group are shown in Table 3 . Total energy intake, carbohydrates intake and lipids intake are similar between groups at baseline. Regarding protein intake, both group have similar amount of protein (total or total $/ \mathrm{kgBW}$ ), amino acid (total, non-essential or essential) and ingested in average $1.2 \mathrm{~g} / \mathrm{KGBW}$. More specifically and by design, we observed a significant difference between group at baseline regarding the amount of protein ingested during the breakfast meal. Moreover, as shown in Table 3, the intervention
(HIIT) did not induce a significant time or within group change on nutritional except for diner protein intake, which increased during the intervention (pre vs. post, $p=0.048$ ) in the $\mathrm{P} 20+$ group only. However, no time $\times$ group effect was observed on nutritional profile or protein intake (quantity or distribution).

\section{Discussion}

The present study shows that HIIT training in obese older adults induces a decrease in waist and hip circumferences and improve functional capacities in both P20- and P20+ groups. Our results, therefore, strengthen the available literature showing that HIIT effectively improves overall muscle function and functional capacities in non-obese older adults $[30,70]$. Our results are also consistent with a recent meta-analysis suggesting that HIT is an effective way to improve $\mathrm{VO}_{2 \max }$ and cardiometabolic risk factors (i.e., waist circumference) in adults [29]. Although the positive effects of HIIT on muscle adaptation in the elderly appear established, this is the first study investigating these effects according to daily protein intake distribution. Our results highlight that ingesting initially at least $20 \mathrm{~g}$ of proteins 
Table 2 Effect of intervention on functional capacities, muscle function and composition

\begin{tabular}{|c|c|c|c|c|c|c|c|c|}
\hline \multirow[t]{2}{*}{ Variables } & \multicolumn{3}{|c|}{ P20- group $(n=15)$} & \multicolumn{3}{|c|}{$\mathrm{P} 20+\operatorname{group}(n=15)$} & \multicolumn{2}{|c|}{$2 * 2$ ANOVA } \\
\hline & Pre & Post & $\begin{array}{l}\text { within-group } \\
\text { effect ( } p \\
\text { value) }\end{array}$ & Pre & Post & $\begin{array}{l}\text { within-group } \\
\text { effect ( } p \\
\text { value) }\end{array}$ & $\begin{array}{l}\text { Time } \\
\text { effect ( } p \\
\text { value) }\end{array}$ & $\begin{array}{l}\text { Time* group } \\
\text { effect ( } p \text { value })\end{array}$ \\
\hline \multicolumn{9}{|l|}{ Functional capacities } \\
\hline Balance $(\times / 60)$ & $26.0 \pm 17.9$ & $42.2 \pm 20.5$ & 0.004 & $33.7 \pm 18.9$ & $39.8 \pm 20.7$ & 0.32 & 0.006 & 0.19 \\
\hline TUGn (s) & $9.98 \pm 1.26$ & $9.04 \pm 1.86$ & 0.006 & $9.64 \pm 0.93$ & $8.55 \pm 0.91$ & 0.001 & $<0.001$ & 0.69 \\
\hline TUGf (s) & $7.31 \pm 1.01$ & $6.46 \pm 1.68$ & 0.003 & $6.99 \pm 0.55$ & $6.15 \pm 0.68$ & 0.002 & $<0.001$ & 0.99 \\
\hline 6 MWT (m) & $556 \pm 91$ & $659 \pm 120$ & $<\mathbf{0 . 0 0 1}$ & $582 \pm 82$ & $648 \pm 72$ & 0.001 & $<0.001$ & 0.18 \\
\hline $\begin{array}{l}\text { Estimated } \mathrm{VO}_{2 \max }(\mathrm{ml} / \mathrm{min} / \\
\mathrm{kg})\end{array}$ & $17.7 \pm 2.1$ & $20.1 \pm 2.8$ & $<0.001$ & $18.3 \pm 1.9$ & $19.9 \pm 1.6$ & 0.001 & $<0.001$ & 0.18 \\
\hline n-4 MWT (s) & $2.95 \pm 0.35$ & $2.70 \pm 0.50$ & 0.05 & $2.95 \pm 0.26$ & $2.71 \pm 0.32$ & 0.004 & 0.001 & 0.95 \\
\hline f-4MWT (s) & $2.06 \pm 0.37$ & $1.88 \pm 0.37$ & 0.022 & $2.07 \pm 0.28$ & $1.86 \pm 0.23$ & 0.002 & $<0.001$ & 0.87 \\
\hline Chair test (s) & $19.9 \pm 5.4$ & $16.3 \pm 4.8$ & 0.001 & $18.1 \pm 3.5$ & $14.4 \pm 3.1$ & $<0.001$ & $<0.001$ & 0.86 \\
\hline Step test $(n)$ & $30.9 \pm 5.4$ & $34.1 \pm 5.7$ & 0.013 & $29.1 \pm 3.6$ & $34.1 \pm 5.1$ & $<0.001$ & $<0.001$ & 0.21 \\
\hline \multicolumn{9}{|l|}{ Muscle function } \\
\hline ULMS (kg) & $32.3 \pm 9.7$ & $33.2 \pm 10.1$ & 0.025 & $33.1 \pm 8.4$ & $33.8 \pm 7.4$ & 0.42 & 0.083 & 0.77 \\
\hline rULMS (kg/kgBW) & $0.42 \pm 0.09$ & $0.44 \pm 0.09$ & 0.025 & $0.41 \pm 0.09$ & $0.42 \pm 0.09$ & 0.51 & 0.059 & 0.41 \\
\hline UMQ (kg/kgLM) & $3.14 \pm 0.46$ & $3.23 \pm 0.39$ & 0.31 & $3.03 \pm 0.49$ & $3.07 \pm 0.51$ & 0.64 & 0.29 & 0.73 \\
\hline LLMS (N) & $324 \pm 99$ & $322 \pm 105$ & 0.89 & $354 \pm 98$ & $387 \pm 89$ & 0.062 & 0.16 & 0.11 \\
\hline rLLMS (kg/kgBW) & $4.24 \pm 1.29$ & $4.33 \pm 1.45$ & 0.62 & $4.39 \pm 1.01$ & $4.76 \pm 0.81$ & 0.11 & 0.11 & 0.32 \\
\hline LMQ (N/kgLM) & $10.3 \pm 2.6$ & $10.1 \pm 2.9$ & 0.76 & $10.1 \pm 2.2$ & $10.9 \pm 1.5$ & 0.12 & 0.28 & 0.14 \\
\hline Muscle Power (W) & $153 \pm 77$ & $179 \pm 81$ & 0.012 & $171 \pm 45$ & $208 \pm 52$ & $<0.001$ & $<0.001$ & 0.31 \\
\hline \multicolumn{9}{|l|}{ Muscle composition } \\
\hline Muscle area $\left(\mathrm{cm}^{2}\right)$ & $100.4 \pm 25.9$ & $95.7 \pm 23.9$ & 0.35 & $99.3 \pm 18.1$ & $102.1 \pm 21.9$ & 0.44 & 0.77 & 0.27 \\
\hline Total fat area $\left(\mathrm{cm}^{2}\right)$ & $69.9 \pm 31.8$ & $66.8 \pm 29.8$ & 0.24 & $91.2 \pm 45.0$ & $89.1 \pm 39.9$ & 0.51 & 0.20 & 0.81 \\
\hline $\begin{array}{l}\text { Total subcutaneous fat area } \\
\left(\mathrm{cm}^{2}\right)\end{array}$ & $65.4 \pm 32.3$ & $61.8 \pm 29.8$ & 0.14 & $85.2 \pm 45.1$ & $85.4 \pm 41.0$ & 0.94 & 0.38 & 0.32 \\
\hline
\end{tabular}

Data are presented as means $\pm \mathrm{SD}$

$P \leq 0.05$ : significant

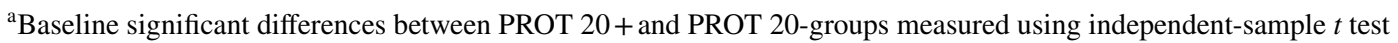

*Within differences between pre- and post-intervention estimated using paired $t$ test. A general linear model repeated measures was conducted to estimate the time and the group $\times$ time effects

$B W$ body weight, $L M$ lean mass, $T U G$ timed up and go, $6 M W T 6$ min walking test, $4 M W T$ 4-m walking test, $U M Q$ upper muscle quality, $L M Q$ lower muscle quality, ULMS upper limbs muscle strength, LLMS lower limbs muscle strength

each meals does not further enhance muscle adaptation in response to HIIT intervention in obese older adults eating at least protein RDA. The present findings are at variance with other results [71] suggesting that a good protein distribution improves functionality, which in turn would be facilitated by combining adequate protein intake with resistance training. However, it recognized that many older people cannot or will not undertake such resistance training [65]. It was therefore interesting to study the effect protein combining with another training modality (e.g., HIIT) on muscle adaptation in older people. There is growing evidence suggesting that higher exercise intensities, even in a shorter period of time (HIIT), have an advantage over moderate-intensity training for maximizing improvements in functional abilities and body composition among the elderly [31-33]. Thus, we decided to focus on this training modality in the present study. Our group also shown divergent results in a previous work showing that protein intake above $1.2 \mathrm{~g} \mathrm{~kg}^{-1} \mathrm{day}^{-1}$ is associated with higher muscle improvements following mixed power training in healthy older men [37]. The divergent results with this previous study could be explained by the different modality training (mixed-power training vs. HIIT) and the selection criteria of the population (health older men vs. obese men and women). The lack of significant results in our study could also be explained by the fact that the P20- group still consume a high quantity of protein during lunch and dinner. In a recent randomized controlled trial [39], no differences in lean body mass, strength and functional capacities of older adults was observed after an 8 -week of dietary intervention based on protein pattern 
Table 3 Effect of intervention on energy balance

\begin{tabular}{|c|c|c|c|c|c|c|c|c|}
\hline \multirow[t]{2}{*}{ Variables } & \multicolumn{3}{|c|}{ P20- group $(n=15)$} & \multicolumn{3}{|c|}{$\mathrm{P} 20+\operatorname{group}(n=15)$} & \multicolumn{2}{|c|}{$2 * 2$ ANOVA } \\
\hline & Pre & Post & $\begin{array}{l}\text { within-group } \\
\text { effect ( } p \\
\text { value) }\end{array}$ & Pre & Post & $\begin{array}{l}\text { within-group } \\
\text { effect ( } p \\
\text { value) }\end{array}$ & $\begin{array}{l}\text { Time } \\
\text { effect ( } p \\
\text { value) }\end{array}$ & $\begin{array}{l}\text { Time } \times \text { group } \\
\text { effect }(p \text { value })\end{array}$ \\
\hline \multicolumn{9}{|l|}{ Energy balance } \\
\hline Number of steps $(\mathrm{n} / \mathrm{d})$ & $6538 \pm 3371$ & $6030 \pm 1930$ & 0.62 & $7317 \pm 2851$ & $7340 \pm 2940$ & 0.98 & 0.72 & 0.69 \\
\hline Mets average & $1.17 \pm 0.17$ & $1.19 \pm 0.19$ & 0.64 & $1.20 \pm 0.10$ & $1.17 \pm 0.11$ & 0.17 & 0.77 & 0.25 \\
\hline Proteins intake $(\mathrm{g} / \mathrm{d})$ & $87.2 \pm 18.0$ & $79.2 \pm 26.7$ & 0.42 & $98.4 \pm 20.2$ & $94.9 \pm 19.9$ & 0.54 & 0.29 & 0.67 \\
\hline $\begin{array}{l}\text { Proteins intake (g/ } \\
\text { kgBW/d) }\end{array}$ & $1.17 \pm 0.20$ & $1.11 \pm 0.43$ & 0.64 & $1.22 \pm 0.24$ & $1.17 \pm 0.25$ & 0.50 & 0.44 & 0.91 \\
\hline $\begin{array}{l}\text { Breakfast protein intake } \\
(\mathrm{g})\end{array}$ & $14.2 \pm 4.9^{\mathrm{a}}$ & $15.2 \pm 6.1$ & 0.69 & $24.0 \pm 6.7^{\mathrm{a}}$ & $20.2 \pm 7.8$ & 0.10 & 0.47 & 0.47 \\
\hline Lunch protein intake $(\mathrm{g})$ & $24.1 \pm 14.9$ & $21.1 \pm 12.1$ & 0.57 & $29.9 \pm 8.7$ & $26.9 \pm 6.8$ & 0.67 & 0.28 & 0.98 \\
\hline Diner protein intake $(\mathrm{g})$ & $38.5 \pm 18.1$ & $36.1 \pm 20.7$ & 0.72 & $33.8 \pm 11.2$ & $39.9 \pm 12.0$ & 0.048 & 0.58 & 0.21 \\
\hline Total EAA (g) & $26.6 \pm 7.1$ & $23.9 \pm 11.3$ & 0.49 & $29.2 \pm 6.6$ & $25.2 \pm 6.7$ & 0.075 & 0.11 & 0.76 \\
\hline Total NEAA (g) & $24.7 \pm 6.9$ & $20.8 \pm 9.2$ & 0.28 & $26.4 \pm 6.3$ & $23.1 \pm 6.4$ & 0.072 & 0.054 & 0.90 \\
\hline
\end{tabular}

Data are presented as means $\pm \mathrm{SD}$

$P \leq 0.05$ : significant

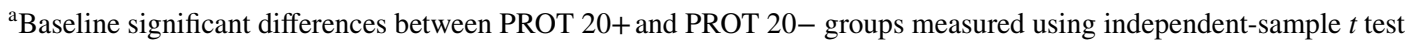

*Within differences between pre- and post-intervention estimated using paired $t$ test. A general linear model repeated measures was conducted to estimate the time and the group $\times$ time effects

$B W$ body weight, $E A A$ essential amino acid, NEAA non-essential amino acid

(i.e., even distribution vs. uneven distribution). However, these results are difficult to compare with ours since the protein intake distribution pattern was studied without any exercise intervention, in non-obese and younger population $(58.1 \pm 2.4$ and $60.3 \pm 2.4$ years vs. $66.8 \pm 3.7$ and $68.1 \pm 4.1$ years) and the study was shorter ( 8 vs. 12 weeks).

An age-associated anabolic resistance to protein containing meals may be a potential explanation to the absence of significant results [72, 73]. To limit the effect of this possible anabolic resistance, we based on the cut-off of $20 \mathrm{~g}$ of protein per meal as proposed previously to maximally stimulate muscle protein synthesis in older adults [19]. Another study also suggests that the optimal protein dose for maximal muscle protein synthesis in older adults is $0.40 \mathrm{~g} \mathrm{~kg}^{-1}$ per meal [23] and we were above this threshold in our experimental study.

Despite the innovative nature of the present study, including a wide range of measures using validated techniques, it has some limitations. First of all, because of the size of the sample, it is possible that the lack of beneficial effect of an even distribution of protein intake might just reflects a type II error. Always because of the small sample size, sexspecific analyzes could not be performed even if Dulac et al. showed significant effect of protein associated with exercise in elderly men [37]. However, according to our calculation, our sample allows to have a statistical power of $70 \%$. Also note that a similar $\mathrm{n}$ is used in other studies with a similar design [74]. Then, since protein distribution was not in the initial design but studied a posteriori, randomized controlled trials (such as even and non even groups with or without RDA) will be needed to confirm our results. Nevertheless, it is worth noting that a wide range of assessments using validated techniques were used in the present study.

\section{Conclusion}

A 12-week HIIT program improves functional capacities as well as body composition in obese older adults. However, if obese older adults are following recommended dietary protein allowances, eating $20 \mathrm{~g}$ of proteins in each meal does not further improve muscle adaptation in response to the HIIT intervention. Altogether, these findings indicate that HIIT is a practical, feasible and efficient training modality, independently of meal protein distribution, and that clinicians should be aware of it and recommend it to their patients that are at risks of muscle performance and mobility decline. 
Fig. 1 Effect of intervention on functional capacities and muscle power. Data are presented as means $\pm \mathrm{SD}$. $P \leq 0.05$ : significant. ${ }^{\mathrm{a} B}$ Baseline significant differences between PROT 20+ and PROT 20- groups measured using independentsample $t$ test. *Within differences between pre- and post-intervention estimated using paired $t$ test. A general linear model repeated measures was conducted to estimate the time and the group $\times$ time effects. $* p<0.05 ; * * p<0.01$; $* * * p<0.001$
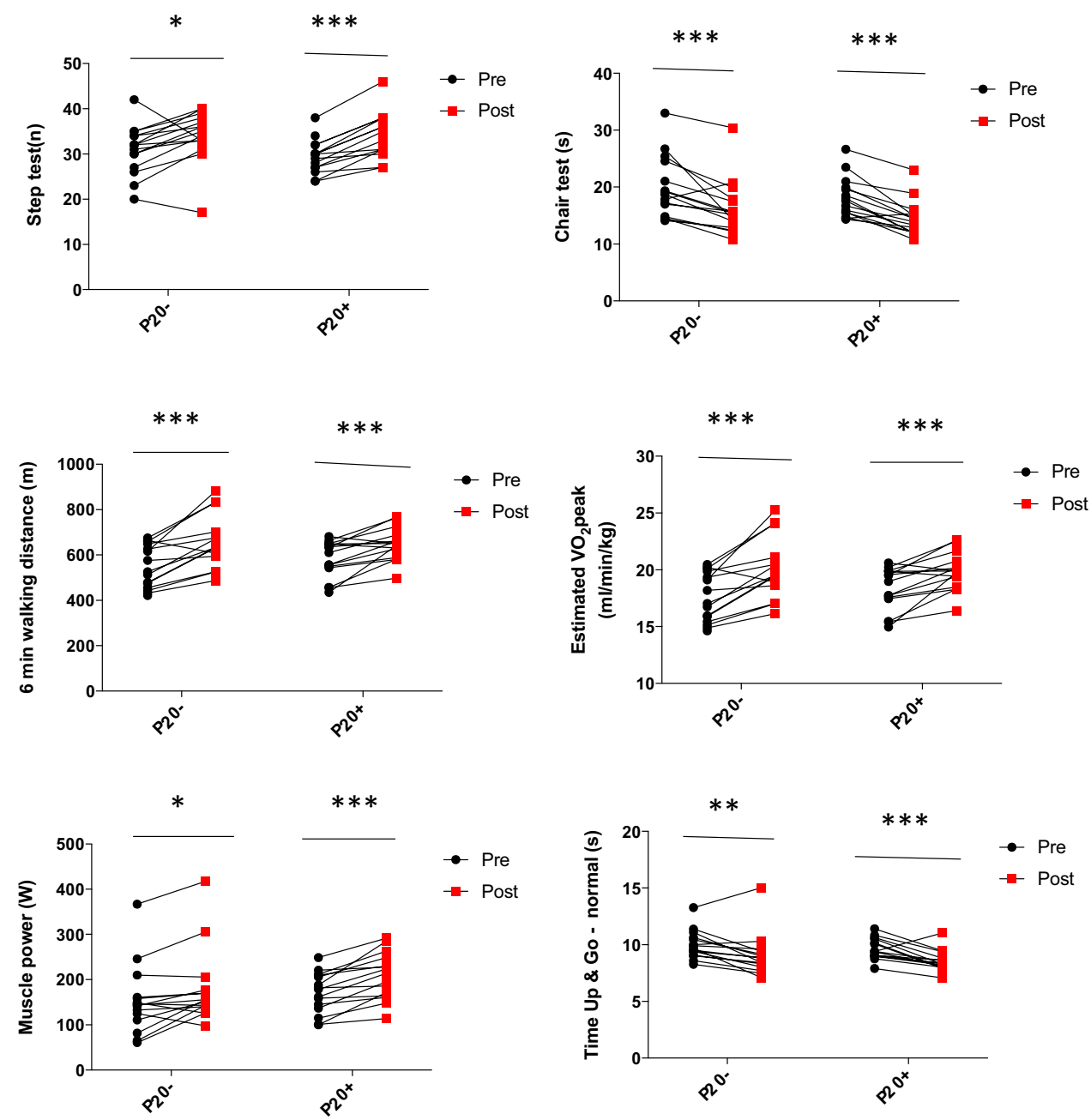

Acknowledgements This study was supported by the Fonds de Recherche du Québec en Santé (FRQS) - Université du Québec à Montréal fund and by the Quebec Network for Research on Aging, a thematic network supported by the FRQS (QNRA-FRQS) and the Canada Foundation for Innovation. MAL is recipient of Chercheur Boursier Junior 2 salary awards from the FRQS. DM is recipient of PhD scholarship from the FRQS. The authors are grateful to all the volunteers for their participation in this study and to Carole Roy for her technical support.

\section{Compliance with ethical standards}

Conflict of interest The authors declare no conflict of interest.

Ethical approval All procedures were approved by the Ethics Committee of the Université du Québec à Montréal (UQAM).

Informed consent All participants provided informed written consent after having received information on nature, goal, procedures and risks associated with the study.

\section{References}

1. Phillips SM, Chevalier S, Leidy HJ (2016) Protein "requirements" beyond the RDA: implications for optimizing health. Appl Physiol Nutr Metab 41:565-572. https://doi.org/10.1139/apnm-2015-0550

2. Janssen I (2010) Evolution of sarcopenia research. Appl Physiol Nutr Metab 35:707-712. https://doi.org/10.1139/h10-067

3. Stuck AE, Walthert JM, Nikolaus T, Bula CJ, Hohmann C, Beck JC (1999) Risk factors for functional status decline in communityliving elderly people: a systematic literature review. Social Sci Med 48:445-469

4. Janssen I (2006) Influence of sarcopenia on the development of physical disability: the Cardiovascular Health Study. J Am Geriatr Soc 54:56-62. https://doi.org/10.1111/j.1532-5415.2005.00540.x

5. Kim JS, Wilson JM, Lee SR (2010) Dietary implications on mechanisms of sarcopenia: roles of protein, amino acids and antioxidants. J Nutr Biochem 21:1-13. https://doi.org/10.1016/j.jnutb io.2009.06.014

6. Cruz-Jentoft AJ, Baeyens JP, Bauer JM, Boirie Y, Cederholm T, Landi F, Martin FC, Michel JP, Rolland Y, Schneider SM, Topinkova E, Vandewoude M, Zamboni M (2010) Sarcopenia: European consensus on definition and diagnosis: Report of the European Working Group on Sarcopenia in Older People. Age ageing 39:412-423. https://doi.org/10.1093/ageing/afq034 
7. Gingrich A, Spiegel A, Kob R, Schoene D, Skurk T, Hauner H, Sieber CC, Volkert D, Kiesswetter E (2017) Amount, distribution, and quality of protein intake are not associated with muscle mass, strength, and Power in healthy older adults without functional limitations—an enable study. Nutrients 9. https://doi.org/10.3390/ nu9121358

8. Phillips SM (2016) The impact of protein quality on the promotion of resistance exercise-induced changes in muscle mass. Nutr Metab 13:64. https://doi.org/10.1186/s12986-016-0124-8

9. Hoffman JR, Falvo MJ (2004) Protein - Which is Best? J Sports Sci Med 3:118-130

10. Katsanos CS, Kobayashi H, Sheffield-Moore M, Aarsland A, Wolfe RR (2006) A high proportion of leucine is required for optimal stimulation of the rate of muscle protein synthesis by essential amino acids in the elderly. Am J Physiol Endocrinol Metab 291:E381-E387. https://doi.org/10.1152/ajpendo.00488 .2005

11. Bauer J, Biolo G, Cederholm T, Cesari M, Cruz-Jentoft AJ, Morley JE, Phillips S, Sieber C, Stehle P, Teta D, Visvanathan R, Volpi E, Boirie Y (2013) Evidence-based recommendations for optimal dietary protein intake in older people: a position paper from the PROT-AGE Study Group. J Am Med Dir Assoc 14:542-559. https://doi.org/10.1016/j.jamda.2013.05.021

12. Gingrich A, Spiegel A, Gradl JE, Skurk T, Hauner H, Sieber CC, Volkert D, Kiesswetter E (2018) Daily and per-meal animal and plant protein intake in relation to muscle mass in healthy older adults without functional limitations: an enable study. Aging Clin Exp Res. https://doi.org/10.1007/s40520-018-1081-z

13. Volpi E, Campbell WW, Dwyer JT, Johnson MA, Jensen GL, Morley JE, Wolfe RR (2013) Is the optimal level of protein intake for older adults greater than the recommended dietary allowance? J Gerontol Series A, Biol Sci Med Sci 68:677-681. https://doi.org/10.1093/gerona/gls229

14. Trumbo P, Schlicker S, Yates AA, Poos M (2002) Dietary reference intakes for energy, carbohydrate, fiber, fat, fatty acids, cholesterol, protein and amino acids. J Am Diet Assoc 102:1621-1630

15. Houston DK, Nicklas BJ, Ding J, Harris TB, Tylavsky FA, Newman AB, Lee JS, Sahyoun NR, Visser M, Kritchevsky SB (2008) Dietary protein intake is associated with lean mass change in older, community-dwelling adults: the Health, Aging, and Body Composition (Health ABC) Study. Am J Clin Nutr 87:150-155. https://doi.org/10.1093/ajen/87.1.150

16. Buckinx F, Allepaerts S, Paquot N, Reginster JY, de Cock C, Petermans J, Bruyere O (2017) Energy and nutrient content of food served and consumed by nursing home residents. J Nutr Health Aging 21:727-732. https://doi.org/10.1007/s1260 3-016-0782-2

17. Gregorio L, Brindisi J, Kleppinger A, Sullivan R, Mangano KM, Bihuniak JD, Kenny AM, Kerstetter JE, Insogna KL (2014) Adequate dietary protein is associated with better physical performance among post-menopausal women $60-90$ years. J Nutr Health Aging 18:155-160. https://doi.org/10.1007/s12603-013-0391-2

18. Farsijani S, Payette H, Morais JA, Shatenstein B, Gaudreau P, Chevalier S (2017) Even mealtime distribution of protein intake is associated with greater muscle strength, but not with 3-y physical function decline, in free-living older adults: the Quebec longitudinal study on Nutrition as a Determinant of Successful Aging (NuAge study). Am J Clin Nutr 106:113-124. https://doi. org/10.3945/ajen.116.146555

19. Moore DR, Robinson MJ, Fry JL, Tang JE, Glover EI, Wilkinson SB, Prior T, Tarnopolsky MA, Phillips SM (2009) Ingested protein dose response of muscle and albumin protein synthesis after resistance exercise in young men. Am J Clin Nutr 89:161-168. https://doi.org/10.3945/ajen.2008.26401
20. Farsijani S, Morais JA, Payette H, Gaudreau P, Shatenstein B, Gray-Donald K, Chevalier S (2016) Relation between mealtime distribution of protein intake and lean mass loss in free-living older adults of the NuAge study. Am J Clin Nutr 104:694-703. https://doi.org/10.3945/ajcn.116.130716

21. Bollwein J, Diekmann R, Kaiser MJ, Bauer JM, Uter W, Sieber CC, Volkert D (2013) Distribution but not amount of protein intake is associated with frailty: a cross-sectional investigation in the region of Nurnberg. Nutr J 12:109. https://doi. org/10.1186/1475-2891-12-109

22. Bouillanne O, Curis E, Hamon-Vilcot B, Nicolis I, Chretien P, Schauer N, Vincent JP, Cynober L, Aussel C (2013) Impact of protein pulse feeding on lean mass in malnourished and at-risk hospitalized elderly patients: a randomized controlled trial. Clin Nutr (Edinburgh Scotland) 32:186-192. https://doi.org/10.1016/j. clnu.2012.08.015

23. Mamerow MM, Mettler JA, English KL, Casperson SL, ArentsonLantz E, Sheffield-Moore M, Layman DK, Paddon-Jones D (2014) Dietary protein distribution positively influences $24-\mathrm{h}$ muscle protein synthesis in healthy adults. J Nutr 144:876-880. https://doi. org/10.3945/jn.113.185280

24. Gray M, Powers M, Boyd L, Garver K (2018) Longitudinal comparison of low- and high-velocity resistance training in relation to body composition and functional fitness of older adults. Aging Clin Exper Res 30:1465-1473. https://doi.org/10.1007/s4052 0-018-0929-6

25. Barbat-Artigas S, Dupontgand S, Pion $\mathrm{CH}$, Feiter-Murphy Y, Aubertin-Leheudre M (2014) Identifying recreational physical activities associated with muscle quality in men and women aged 50 years and over. J Cachexia Sarcopenia Muscle 5:221-228. https ://doi.org/10.1007/s13539-014-0143-0

26. Gibala MJ (2007) High-intensity interval training: a time-efficient strategy for health promotion? Curr Sports Med Rep 6:211-213

27. Coetsee C, Terblanche E (2017) The effect of three different exercise training modalities on cognitive and physical function in a healthy older population. Eur Rev Aging Phys Activity 14:13. https://doi.org/10.1186/s11556-017-0183-5

28. Fex A, Leduc-Gaudet JP, Filion ME, Karelis AD, Aubertin-Leheudre M (2015) Effect of elliptical high intensity interval training on metabolic risk factor in pre- and type 2 diabetes patients: a pilot study. J Phys Act Health 12:942-946. https://doi.org/10.1123/ jpah.2014-0123

29. Batacan RB Jr, Duncan MJ, Dalbo VJ, Tucker PS, Fenning AS (2017) Effects of high-intensity interval training on cardiometabolic health: a systematic review and meta-analysis of intervention studies. Br J Sports Med 51:494-503. https://doi.org/10.1136/ bjsports-2015-095841

30. Sculthorpe NF, Herbert P, Grace F (2017) One session of highintensity interval training (HIIT) every 5 days, improves muscle power but not static balance in lifelong sedentary ageing men: a randomized controlled trial. Medicine 96:e6040. https://doi. org/10.1097/md.0000000000006040

31. Karlsen T, Aamot IL, Haykowsky M, Rognmo O (2017) High intensity interval training for maximizing health outcomes. Prog Cardiovasc Dis 60:67-77. https://doi.org/10.1016/j. pcad.2017.03.006

32. Gillen JB, Gibala MJ (2014) Is high-intensity interval training a time-efficient exercise strategy to improve health and fitness? Appl Physiol Nutr Metab 39:409-412. https://doi.org/10.1139/ apnm-2013-0187

33. Garcia-Pinillos F, Camara-Perez JC, Soto-Hermoso VM, LatorreRoman PA (2017) A high intensity interval training (HIIT)-based running plan improves athletic performance by improving muscle power. J Strength Cond Res 31:146-153. https://doi.org/10.1519/ jsc.0000000000001473 
34. Thum JS, Parsons G, Whittle T, Astorino TA (2017) Highintensity interval training elicits higher enjoyment than moderate intensity continuous exercise. PloS One 12:e166299. https://doi. org/10.1371/journal.pone.0166299

35. Vella CA, Taylor K, Drummer D (2017) High-intensity interval and moderate-intensity continuous training elicit similar enjoyment and adherence levels in overweight and obese adults. Eur J Sport Sci 17:1203-1211. https://doi.org/10.1080/17461 391.2017.1359679

36. Mitchell CJ, Milan AM, Mitchell SM, Zeng N, Ramzan F, Sharma $\mathrm{P}$, Knowles SO, Roy NC, Sjodin A, Wagner KH, Cameron-Smith D (2017) The effects of dietary protein intake on appendicular lean mass and muscle function in elderly men: a 10-wk randomized controlled trial. Am J Clin Nutr 106:1375-1383. https:// doi.org/10.3945/ajcn.117.160325

37. Dulac MC, Pion CH, Lemieux F, Boutros El Hajj G, Belanger M, Gaudreau P, Chevalier S, Morais JA, Gouspillou G, AubertinLeheudre M (2018) Differences in muscle adaptation to a 12-week mixed power training in elderly men, depending on usual protein intake. Exp Gerontol 104:78-85. https://doi.org/10.1016/j.exger .2018.02.001

38. Hudson JL, Kim JE, Paddon-Jones D, Campbell WW (2017) Within-day protein distribution does not influence body composition responses during weight loss in resistance-training adults who are overweight. Am J Clin Nutr 106:1190-1196. https://doi. org/10.3945/ajen.117.158246

39. Kim IY, Schutzler S, Schrader AM, Spencer HJ, Azhar G, Wolfe RR, Ferrando AA (2018) Protein intake distribution pattern does not affect anabolic response, lean body mass, muscle strength or function over 8 weeks in older adults: A randomized-controlled trial. Clin Nutr (Edinburgh Scotland) 37:488-493. https://doi. org/10.1016/j.clnu.2017.02.020

40. Baumgartner RN, Wayne SJ, Waters DL, Janssen I, Gallagher D, Morley JE (2004) Sarcopenic obesity predicts instrumental activities of daily living disability in the elderly. Obes Res 12:19952004. https://doi.org/10.1038/oby.2004.250

41. Chen MJ, Fan X, Moe ST (2002) Criterion-related validity of the Borg ratings of perceived exertion scale in healthy individuals: a meta-analysis. J Sports Sci 20:873-899. https://doi. org/10.1080/026404102320761787

42. Karvonen J, Vuorimaa T (1988) Heart rate and exercise intensity during sports activities. Practical application. Sports Med 5:303-311

43. Williams JE, Wells JC, Wilson CM, Haroun D, Lucas A, Fewtrell MS (2006) Evaluation of Lunar Prodigy dual-energy X-ray absorptiometry for assessing body composition in healthy persons and patients by comparison with the criterion 4-component model. Am J Clin Nutr 83:1047-1054

44. Kiebzak GM, Leamy LJ, Pierson LM, Nord RH, Zhang ZY (2000) Measurement precision of body composition variables using the lunar DPX-L densitometer. J Clin Densitom 3:35-41

45. ATS statement: guidelines for the six-minute walk test (2002) Am J Respir Crit Care Med 166:111-117. https://doi.org/10.1164/ ajrccm.166.1.at1102

46. Burr JF, Bredin SS, Faktor MD, Warburton DE (2011) The 6-minute walk test as a predictor of objectively measured aerobic fitness in healthy working-aged adults. Phys Sports Med 39:133-139. https://doi.org/10.3810/psm.2011.05.1904

47. Munoz-Mendoza CL, Cabanero-Martinez MJ, Millan-Calenti JC, Cabrero-Garcia J, Lopez-Sanchez R, Maseda-Rodriguez A (2011) Reliability of 4-m and 6-m walking speed tests in elderly people with cognitive impairment. Arch Gerontol Geriatr 52:e67-e70. https://doi.org/10.1016/j.archger.2010.06.020

48. Unver B, Baris RH, Yuksel E, Cekmece S, Kalkan S, Karatosun V (2017) Reliability of 4-meter and 10-meter walk tests after lower extremity surgery. Disabil Rehabil 39:2572-2576. https://doi. org/10.1080/09638288.2016.1236153

49. Podsiadlo D, Richardson S (1991) The timed "Up \& Go": a test of basic functional mobility for frail elderly persons. J Am Geriatr Soc 39:142-148

50. Mathias S, Nayak US, Isaacs B (1986) Balance in elderly patients: the "get-up and go" test. Arch Phys Med Rehabil 67:387-389

51. Yanagawa N, Shimomitsu T, Kawanishi M, Fukunaga T, Kanehisa H (2016) Relationship between performances of 10-timerepeated sit-to-stand and maximal walking tests in non-disabled older women. J Physiol Anthropol 36:2. https://doi.org/10.1186/ s40101-016-0100-z

52. Chung MM, Chan RW, Fung YK, Fong SS, Lam SS, Lai CW, Ng SS (2014) Reliability and validity of Alternate Step Test times in subjects with chronic stroke. J Rehabil Med 46:969-974. https:// doi.org/10.2340/16501977-1877

53. Berg KO, Wood-Dauphinee SL, Williams JI, Maki B (1992) Measuring balance in the elderly: validation of an instrument. Can J Publ health 83(Suppl 2):S7-S11

54. Springer BA, Marin R, Cyhan T, Roberts H, Gill NW (2007) Normative values for the unipedal stance test with eyes open and closed. J Geriat Phys Ther 30:8-15

55. Mathiowetz V, Weber K, Volland G, Kashman N (1984) Reliability and validity of grip and pinch strength evaluations. J Hand Surg 9:222-226

56. Dulac M, Boutros GE, Pion C, Barbat-Artigas S, Gouspillou G, Aubertin-Leheudre M (2016) Is handgrip strength normalized to body weight a useful tool to identify dynapenia and functional incapacity in post-menopausal women? Braz J Phys Ther 20:510 516. https://doi.org/10.1590/bjpt-rbf.2014.0184

57. Houtz SJ, Lebow MJ, Beyer FR (1957) Effect of posture on strength of the knee flexor and extensor muscles. J Appl Physiol 11:475-480

58. Williams M, Stutzman L (1959) Strength variation through the range of joint motion. Phys Ther Rev 39:145-152

59. Riggs BL, Wahner HW, Dunn WL, Mazess RB, Offord KP, Melton LJ 3rd (1981) Differential changes in bone mineral density of the appendicular and axial skeleton with aging: relationship to spinal osteoporosis. J Clin Investig 67:328-335. https://doi. org/10.1172/JCI110039

60. Barbat-Artigas S, Rolland Y, Cesari M, Abellan van Kan G, Vellas B, Aubertin-Leheudre M (2013) Clinical relevance of different muscle strength indexes and functional impairment in women aged 75 years and older. J Gerontol Ser A, Biol Sci Med Sci 68:811-819. https://doi.org/10.1093/gerona/gls254

61. Verdijk LB, van Loon L, Meijer K, Savelberg HH (2009) One-repetition maximum strength test represents a valid means to assess leg strength in vivo in humans. J Sports Sci 27:59-68. https://doi. org/10.1080/02640410802428089

62. Newman AB, Kupelian V, Visser M, Simonsick EM, Goodpaster BH, Kritchevsky SB, Tylavsky FA, Rubin SM, Harris TB (2006) Strength, but not muscle mass, is associated with mortality in the health, aging and body composition study cohort. J Gerontol Series A, Biol Sci Med Sci 61:72-77

63. Bassey EJ, Short AH (1990) A new method for measuring power output in a single leg extension: feasibility, reliability and validity. Eur J Appl Physiol 60:385-390

64. Skelton DA, Kennedy J, Rutherford OM (2002) Explosive power and asymmetry in leg muscle function in frequent fallers and nonfallers aged over 65. Age Ageing 31:119-125

65. Blew RM, Lee VR, Farr JN, Schiferl DJ, Going SB (2014) Standardizing evaluation of pQCT image quality in the presence of subject movement: qualitative versus quantitative assessment. Calcif Tissue Int 94:202-211

66. Doube M, Kłosowski MM, Arganda-Carreras I, Cordelières FP, Dougherty RP, Jackson JS, Schmid B, Hutchinson JR, Shefelbine 
SJ (2010) BoneJ: free and extensible bone image analysis in ImageJ. Bone 47:1076-1079

67. Frank-Wilson AW, Johnston JD, Olszynski WP, Kontulainen SA (2015) Measurement of muscle and fat in postmenopausal women: precision of previously reported pQCT imaging methods. Bone 75:49-54

68. Brazeau AS, Beaudoin N, Belisle V, Messier V, Karelis AD, Rabasa-Lhoret R (2016) Validation and reliability of two activity monitors for energy expenditure assessment. J Sci Med Sport 19:46-50. https://doi.org/10.1016/j.jsams.2014.11.001

69. Colbert LH, Matthews CE, Havighurst TC, Kim K, Schoeller DA (2011) Comparative validity of physical activity measures in older adults. Med Sci Sports Exerc 43:867-876. https://doi.org/10.1249/ MSS.0b013e3181fc7162

70. Buckley S, Knapp K, Lackie A, Lewry C, Horvey K, Benko C, Trinh J, Butcher S (2015) Multimodal high-intensity interval training increases muscle function and metabolic performance in females. Appl Physiol Nutr Metab 40:1157-1162. https://doi. org/10.1139/apnm-2015-0238

71. Dawson BM, Axford S (2014) Nutrition as a part of healthy aging and reducing cardiovascular risk: improving functionality in later life using quality protein, with optimized timing and distribution. Semin Thromb Hemost 40:695-703. https://doi. org/10.1055/s-0034-1389081

72. Moore DR, Churchward-Venne TA, Witard O, Breen L, Burd NA, Tipton KD, Phillips SM (2015) Protein ingestion to stimulate myofibrillar protein synthesis requires greater relative protein intakes in healthy older versus younger men. J Gerontol Series A, Biol Sci Med Sci 70:57-62. https://doi.org/10.1093/gerona/glu10 3

73. Burd NA, Gorissen SH, van Loon LJ (2013) Anabolic resistance of muscle protein synthesis with aging. Exerc Sport Sci Rev 41:169-173. https://doi.org/10.1097/JES.0b013e318292f3d5

74. Maltais M, Du Bois-Dit-Bonclaude M, Amamou T, Riesco E, Dionne IJ (2018) The impact of post-resistance exercise protein consumption on subsequent appetite and daily energy intake of sarcopenic older men: a pilot study. Aging Clin Exp Res 30:10871092. https://doi.org/10.1007/s40520-017-0880-y

Publisher's Note Springer Nature remains neutral with regard to jurisdictional claims in published maps and institutional affiliations. 